\title{
ACCUMULATION OF PHYTOALEXINS IN BEANS, SOYBEANS AND SORGHUM BY FUNGAL FILTRATES ${ }^{1}$
}

\author{
ANTÔNIO JUSSIÊ DA SILVA SOLINO ${ }^{2 *}$, KÁTIA REGINA FREITAS SCHWAN-ESTRADA ${ }^{3}$, JULIANA SANTOS \\ BATISTA OLIVEIRA ${ }^{3}$, LILIANNE MARTINS RIBEIRO ${ }^{4}$, MARIANA FERREIRA SAAB ${ }^{3}$
}

\begin{abstract}
The use of elicitors in plants for disease control is demonstrated by the accumulation of phytoalexins. Among these elicitors, metabolic products from fungi have been shown to be effective in the activation of mechanisms of induced resistance. Thus, this study aimed to evaluate the effects of filtrates from the saprobic fungi Curvularia inaequalis, Pseudobotrytis terrestris, Memnoniella echinata and Curvularia eragrostidis in inducing phaseolin, glyceolin and deoxyanthocyanidins. For this, fungal mycelial disks were liquid-subcultured in potato dextrose (BD) media and maintained in BOD at $25{ }^{\circ} \mathrm{C}$ and $12 \mathrm{~h}$ of light and darkness. After 20 days, the cultures were filtered and, the filtrates were used in the experiments. Phaseolin was measured in etiolated hypocotyls of bean. For glyceolin evaluation, cotyledons of soybean were used. The deoxyanthocyanidin accumulation was evaluated in etiolated mesocotyls of sorghum. The results were subjected to analysis of variance and compared by regression tests $(\mathrm{p}<0.05)$. The filtrates of the saprobic fungi C. eragrostidis, $C$. inaequalis, $P$. terrestris and $M$. echinata promoted $9,8,9$ and $7 \%$ greater increases in the concentration of phaseolin accumulations, respectively. The glyceolin accumulation varied with the concentration of $C$. eragrostidis, $C$. inaequalis and $P$. terrestris by adjusting the behavior to a cubic model. The deoxyanthocyanidin accumulation increased with concentration, while the filtrates of $M$. echinata and $C$. eragrostidis promoted 2 to 3 times more increases than the application of water. The filtrates of $P$. terrestris, $C$. eragrostidis, $C$. inaequalis and $M$. echinata induced accumulations of phytoalexins in soybean, beans and sorghum.
\end{abstract}

Keywords: Deoxyanthocyanidins. Glyceolin. Phaseolin.

\section{ACÚMULO DE FITOALEXINAS EM FEIJÃO, SOJA E SORGO POR FILTRADOS DE FUNGOS}

RESUMO - O uso de elicitores em plantas para o controle de doenças tem demonstrado ação no acúmulo de fitoalexinas. Dentre estes, produtos do metabolismo de fungos apresentam eficiência na ativação de mecanismos de resistência induzida das plantas. O objetivo deste trabalho foi avaliar o efeito de filtrados dos fungos sapróbios Curvularia inaequalis, Pseudobitritis terrestris, Memnomiella echinata e Curvularia eragrostidis na indução de faseolina, gliceolina e deoxiantocianidinas. Para isso, discos de micélio dos fungos foram repicados em meio líquido $\mathrm{BD}$ (batata e dextrose) e mantidos em B.O.D. a $25^{\circ} \mathrm{C}, 12 \mathrm{~h}$ luz/escuro. Após 20 dias foi realizada filtragem e utilizado os filtrados nos experimentos. A faseolina foi determinada em hipocótilos estiolados de feijão. Para avaliação da gliceolina, foram utilizados cotilédones de plântulas de soja. $\mathrm{O}$ acúmulo de deoxiantocianidinas foi avaliado em mesocótilos estiolados de sorgo. Os Resultados foram submetidos à análise de variância e comparados pelo teste de regressão $(\mathrm{p}<0,05)$. Os filtrados dos fungos sapróbios $C$. erogrostis, $C$. inaequalis, $P$. terrestris e $M$. echinata promoveram maior incremento no acúmulo de faseolina nas concentrações 9, 8, 9 e 7\%, respecivamente. $O$ acúmulo de gliceolina variou com as concentrações dos sapróbios C. erogrostis, C. inaequalis e P. terrestris, ajustando-se o comportamento ao modelo cúbico. $\mathrm{O}$ acúmulo de deoxiantocianidinas aumentou conforme a concentração, enquanto os filtrados de $M$. echinata e $C$. eragrostidis promoveram aumento de 2 e 3 vezes mais que a aplicação de água. A aplicação dos filtrados de $P$. terrestris, C. eragrostidis, $C$. inaequalis e $M$. echinata induziram o acúmulo de fitoalexinas em soja, feijão e sorgo.

Palavras-chave: Faseolina. Gliceolina. Deoxiantocianidinas.

\footnotetext{
${ }^{*}$ Corresponding author

${ }^{1}$ Received for publication in $07 / 03 / 2016$; accepted in $02 / 20 / 2017$

Paper extracted from the doctoral thesis of the first author.

${ }^{2}$ Department of Agronomy, Centro Universitário Uningá, Maringá, PR, Brazil; jussiesolino@hotmail.com.

${ }^{3}$ Department of Agronomy, Universidade do Estado de Maringá, Maringá, PR, Brazil; krfsestrada@gmail.com, julianaglomer@hotmail.com, marianasaab@hotmail.com.

${ }^{4}$ Department of Agronomy, Universidade de Rio Verde, Rio Verde, GO, Brazil; lilianne.mr@hotmail.com.
} 


\section{INTRODUCTION}

Loss of harvest in agriculture due to pathogen attack is a serious problem worldwide. Plants are constantly under attack by many pathogens with high destructive potential. Plants respond to pathogens by the formation of reactive oxygen species (ROS), synthesis of pathogenesis-related proteins (PRPs), activation of defense genes for cell wall reinforcement and production of antimicrobial compounds. Among these antimicrobial compounds are phytoalexins, which are induced during attack or exposure of the plant to an elicitor agent and constitute an important part of the defense repertoire of the plant (PEDRAS et al., 2008, 2009).

A broad spectrum of phytoalexins induced by different pathogenic agents has been described in several plant species (AHUJA et al., 2012; IRITI, FAORO, 2009). Stangarlin et al. (2011) reported that the synthesis of phytoalexins constitutes one of the fastest metabolic responses of plants to the action of external elicitors. Thus, the analysis of these substances represents an important tool in the study of resistance induction events (PEITER-BENINCA et al., 2008; VIECELLI et al., 2009).

Phaseolin, glyceolin and deoxyanthocyanidins are often reported in induction studies, indicating that they can be considered indicators of this type of analysis because they are easily measured and respond effectively to elicitors.

A variety of elicitors have been described in the literature. Among them are biotic agents such as microorganisms that can activate plant defense mechanisms (DUBERY et al., 2012). Phytopathogenic, nonpathogenic and saprobic fungal filtrates can activate plant defense systems, as they have molecules such as proteins, oligosaccharides, oligopeptides and toxins, among others, that function as recognition signatures of the microorganisms; these signatures are recognized by protein receptors present on the cell membrane of the plant cells (DUBERY et al., 2012). To identify inducing agents of plant resistance to pathogens, it is important to observe biochemical changes occurring in the plant, such as the accumulation of phytoalexins (CHOUDHARY; PRAKASH; JOHRI, 2007).

Therefore, the goal of this work was to evaluate the potential of saprobic fungal filtrates in activating defense mechanisms in plants by means of the accumulation of phytoalexins in bean hypocotyls, soybean cotyledons and stenciled mesocotyls of sorghum.

\section{MATERIAL AND METHODS}

The experiments were carried out in the Laboratory of Alternative Control and Induction of Resistance of the State University of Maringá from
January 2012 to December 2013 in Maringá, PR, Brazil.

The filtrates were obtained from repetitions of one disc $(7 \mathrm{~mm})$ of BDA with mycelia of the saprobic fungi $M$. echinata, $C$. eragrostidis, $C$. inaequalis and $P$. terrestris in $100 \mathrm{~mL}$ of PD liquid culture media sterilized at $120{ }^{\circ} \mathrm{C}$ and 1 atm for $20 \mathrm{~min}$. The liquid media containing the saprobic fungi were incubated in a growth chamber at a temperature of $25 \pm 2{ }^{\circ} \mathrm{C}$ and a 12 -h photoperiod for 20 days and then filtered on Whatman \#1 paper to separate the filtrate from the mycelial mass. The filtrates were tested for their capacity to induce the accumulation of phytoalexins in bean (phaseolin), soybean (glyceolin) and sorghum (deoxyanthocyanidins). Filtrations of saprobic fungi $+\mathrm{BD}$ media were used at concentrations of 0 , 5, 10, 15 and 20\%; acibenzolar-s-methyl (ASM) at a concentration of $5 \mathrm{~g} 100 \mathrm{~L}^{-1}$ and sterilized distilled water were used as controls, totaling 26 treatments.

The determination of phaseolin was adopted from the methodology proposed by Dixon et al. (1983). Bean seeds were disinfected with 1\% sodium hypochlorite for $5 \mathrm{~min}$, washed in sterilized distilled water, seeded in sterilized sand and maintained in a climate-controlled chamber at $25 \pm 2{ }^{\circ} \mathrm{C}$ in the dark. After 7 days, stenciled hypocotyl segments were detached from the seedlings and washed in sterilized water. Four hypocotyl segments were weighed and placed into a germination box containing filter paper moistened with distilled water. Different treatments (concentrations of the filtrates) were sprayed onto the hypocotyls, and the germination boxes were kept at $25 \pm 2{ }^{\circ} \mathrm{C}$ in the dark for $48 \mathrm{~h}$. After this period, the hypocotyls were transferred to test tubes containing $10 \mathrm{~mL}$ of ethanol and kept at $4{ }^{\circ} \mathrm{C}$ for $48 \mathrm{~h}$ for phytoalexin extraction. Afterward, the hypocotyls were shaken for $1 \mathrm{~h}$ for extraction and measurement of the formed phaseolin, the latter of which was carried out using a spectrophotometer at $280 \mathrm{~nm}$. The results were expressed as units of absorbance per gram of fresh weight $\left(\mathrm{ABS} \mathrm{g} \mathrm{fw}^{-1}\right)$.

For the induction of glyceolin, soybean seeds (cultivar IAC-8) were sown in sterilized sand and maintained in the greenhouse. After 7 days, the cotyledons were removed from the seedlings, washed in sterilized distilled water, dried and cut to a thickness of approximately $1 \mathrm{~mm}$ and a diameter of $6 \mathrm{~mm}$ on the abaxial surface. Five cotyledons were weighed and placed in a Petri dish containing filter paper moistened with sterilized distilled water. A $75-\mu \mathrm{L}$ aliquot of treatment solution (filtrate $+\mathrm{BD}$ media at a concentration of $0,5,10,15$ or $20 \%$;

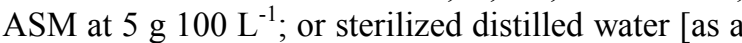
control]) was applied to the cut of each cotyledon. The Petri dishes were kept at $25{ }^{\circ} \mathrm{C}$ in the dark. After $20 \mathrm{~h}$, the cotyledons were transferred to test tubes containing $15 \mathrm{~mL}$ of sterilized distilled water and stirred for $1 \mathrm{~h}$ for phytoalexin extraction. The absorbance was determined at $285 \mathrm{~nm}$ (AYERS et 
al., 1976; ZIEGLER, PONTZEN, 1982), and the results were expressed as absorbance units per gram of fresh weight (ABS $\left.\mathrm{g} \mathrm{fw}^{-1}\right)$.

Sorghum (cultivar Brandes) seeds were used to analyze the induction of deoxyanthocyanidins. Sorghum seeds were disinfected with sodium hypochlorite $(1 \%)$ for $15 \mathrm{~min}$, washed in sterilized water, wrapped in sheets of germination paper moistened with water and incubated in the dark at 25 $\pm 2{ }^{\circ} \mathrm{C}$ for 4 days. Seven days after germination, the seedlings were exposed to light for $4 \mathrm{~h}$ to paralyze the elongation of the mesocotyls (NICHOLSON et al., 1988). The obtained mesocotyls were excised 0.5 $\mathrm{cm}$ above the scutellar node, placed in test tubes containing $1 \mathrm{~mL}$ of each treatment (filtrate $+\mathrm{BD}$ media at a concentration of $5,10,15$ or $20 \%$; ASM at $5 \mathrm{~g} 100 \mathrm{~L}^{-1}$; or sterilized distilled water [as a control]) and kept in a moist chamber at $25{ }^{\circ} \mathrm{C}$ under fluorescent light (WULFF, PASCHOLATI, 1998). After $60 \mathrm{~h}$, the mesocotyls were removed from the tubes, and the 5-mm portion of the basal end of each mesocotyl was excised and discarded. The upper portion was weighed, cut into small segments and placed in microcentrifuge tubes containing $1.4 \mathrm{~mL}$ of $80 \%$ acidified methanol $(0.1 \% \mathrm{HCl} ; \mathrm{v} / \mathrm{v})$. The cut mesocotyls were maintained at $4{ }^{\circ} \mathrm{C}$ for $96 \mathrm{~h}$ for phytoalexin extraction, and the absorbance was determined at $480 \mathrm{~nm}$ (NICHOLSON et al., 1987, 1988). The results were expressed as units of absorbance per gram of fresh weight $\left(\mathrm{ABS} g \mathrm{fw}^{-1}\right)$.

The bioassays of phytoalexin induction were conducted in a completely randomized design with four repetitions. The data were subjected to the Shapiro-Wilk normality test and, assuming the assumption for the analysis of variance was met, when significant were subjected to regression analysis $(\mathrm{p}<0.05)$, with a control and additional control treatment.

\section{RESULTS AND DISCUSSION}

By analyzing the influence of the concentrations of saprobic fungi on phytoalexin induction, an increase in the accumulation of phytoalexins was observed in all treatments. Based on the regression analysis, concentrations of $C$. eragrostidis, $C$. inaequalis, $P$. terrestris and $M$. echinata $(9,8,9$ and $7 \%$, respectively) promoted higher accumulations of phaseolin in bean hypocotyls, with increases of 8, 7, 10 and 9 fold, respectively, compared with those from the water treatment. When comparing ASM, the filtrates of $C$. eragrostidis, $C$. inaequalis, $P$. terrestris and $M$. echinata promoted higher accumulations of phaseolin, with increases of 1.7, 1.2, 2.1 and 2.1 fold, respectively (Figure 1).

When studying the fractionation of Colletotrichum lindemuthianum, $C$. trifoli and $C$. destructivum, Anderson (1977) observed that the application of $100 \mu \mathrm{L}$ promoted phytoalexin induction in bean cotyledons and that the glucan was essential in the activation of defense responses in the seedlings. The author also verified the presence of glucose, mannose and rhamnose, which may be involved in the cotyledon defense response. Although fractionation of the filtrates was not performed in this work, as was used by Anderson (1977), it can be inferred that the saprobic filtrates have molecules capable of increasing the accumulation of phaseolin in bean seedlings.

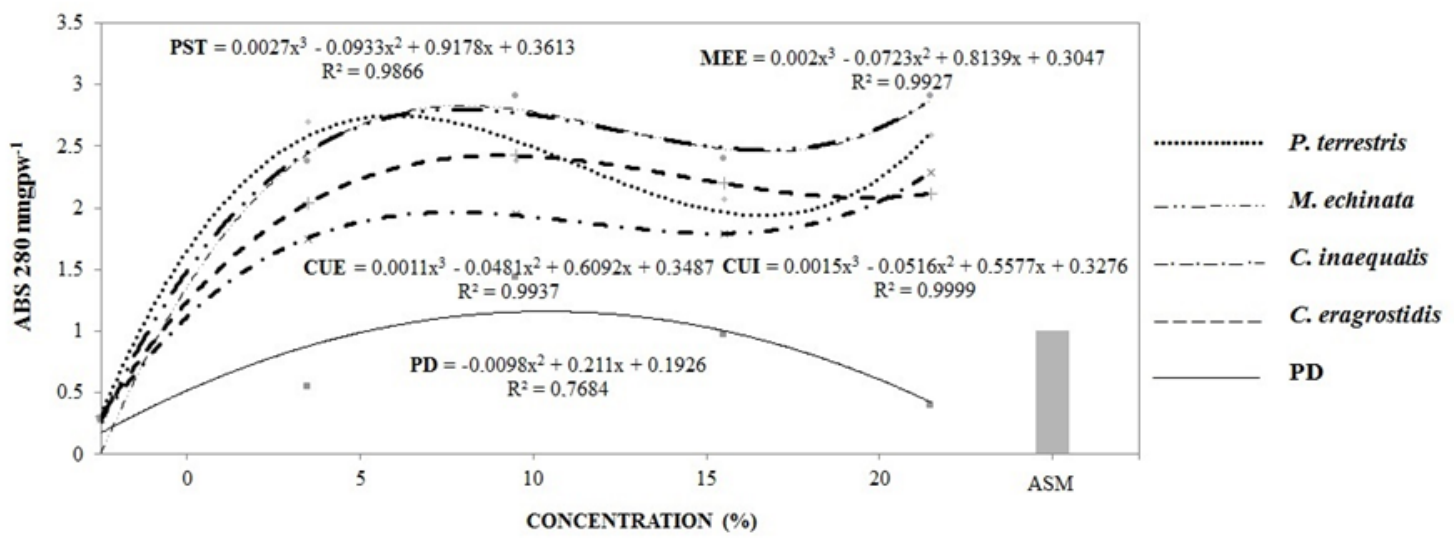

Figure 1. Accumulation of phaseolin in bean hypocotyls as a function of the application of filtrates of the saprobic fungi Memnoniella echinata, Curvularia eragrostidis, C. inaequalis and Pseudobotrytis terrestris at different concentrations. Potato dextrose (BD). Acibenzolar-S-methyl (ASM).

The glyceolin accumulation varied significantly $(\mathrm{P}<0.05)$ with the concentration of the saprobes $C$. inaequalis, $C$. eragrostidis and $P$. terrestris after adjusting the fit to the cubic model, with the exception of the concentrations of
M. echinata that did not present significance. The filtrates of $C$. inaequalis at a concentration of $5.4 \%$ promoted 3 and 5 times more accumulation of phaseolin in bean seedlings than the water- and ASM-treated hypocotyls, respectively. As for 
C. eragrostidis, 3 times more phaseolin was observed with the application of the filtrate in bean hypocotyls compared with the control treatments (water and ASM) (Figure 2). Similar results were found by Simões et al. (2005), who verified five- and six-fold increases in the phytoalexin accumulation in soybean when applying preparations from $\beta$-glucan isolated from Phytophthora sojae and from spores of Mucor ramosissimus, respectively.

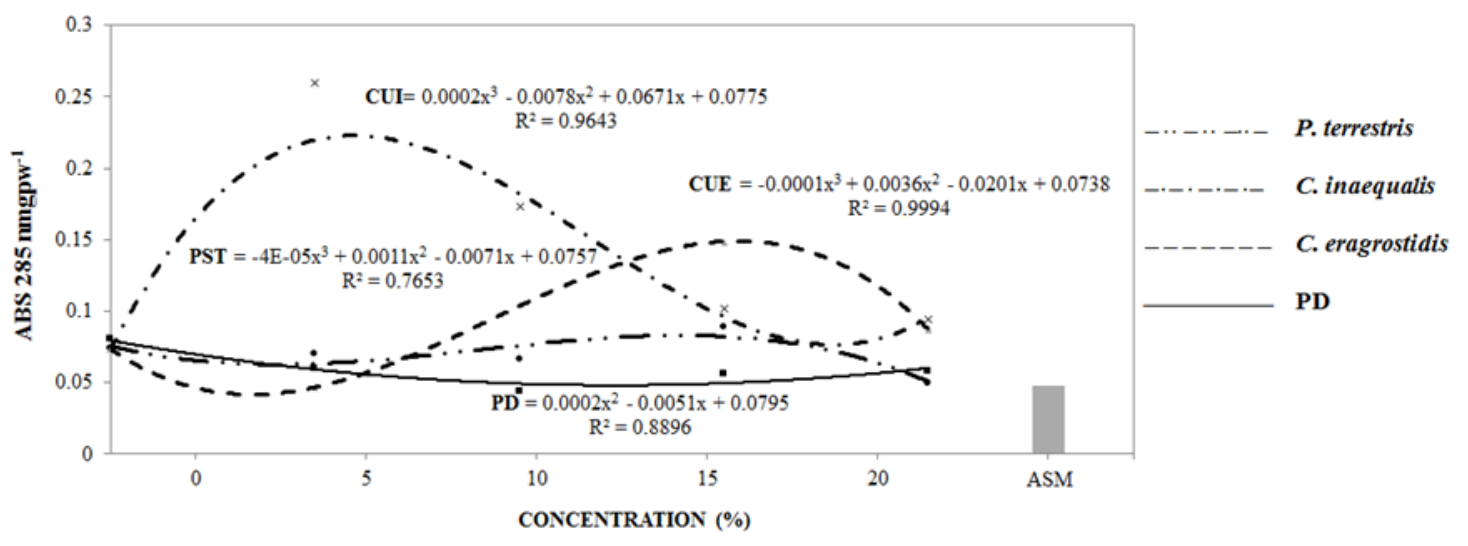

Figure 2. Accumulation of phytoalexins in soybean cotyledons as a function of the filtrate applications of the saprobic fungi Memnoniella echinata, Curvularia eragrostidis, C. inaequalis and Pseudobotrytis terrestris at different concentrations. Potato dextrose (BD). Acibenzolar-S-methyl (ASM).

As in this work, Arruda et al. (2012) evaluated the effects of different concentrations (1, 2, 4 and 10\%) of aqueous extracts of Agaricus blazei, Lentinula edodes and Pycnoporus sanguineus on the induction of glyceolin and observed a higher accumulation of phytoalexins with higher concentrations of the aqueous extracts. According to Mazaro et al. (2008), alcoholic extracts, decoction, infusion and maceration of pitangueira induce the phytoalexin glyceolin in cotyledons of soybean. The induction effect was characterized by the increase of the concentrations of the preparations and among the evaluated concentrations; those that presented greater responses were the alcoholic extract at concentrations of 10 and $40 \%$, infusion at $40 \%$ concentration, decoction at $40 \%$ concentration and maceration at concentrations of 10 and $40 \%$. Mazaro et al. (2013) observed variation in the line behavior, such as that with the quadratic and cubic models in this work, and observed that preparations of Calendula officinalis also induced glyceolin at a concentration of $10 \%$, whereas the alcoholic extract showed higher glyceolin accumulation at a concentration of $5 \%$.

The accumulation of deoxyanthocyanidins in sorghum mesocotyls increased according to the concentration of the filtrates of $C$. inaequalis and $P$. terrestris. The filtrate of $C$. inaequalis promoted the accumulation of deoxyanthocyanidins by 3 and 0.7 fold in relation to the control and the ASM at
$20 \%$ concentration, respectively. The filtrates of $M$. echinata and C. eragrostidis promoted 2- and 3-fold increases in deoxyanthocyanidins at concentrations of 6 and 14\% compared with those of the control, respectively, and 0.5 - and 1-fold increases compared with those of ASM, respectively (Figure 3). Other studies have also reported the action of fungal filtrates on the induction of deoxyanthocyanidins. Stangarlin et al. (2010) observed inducing potential of deoxyanthocyanidins and glyceolin when studying the induction of phytoalexins by the yeast Saccharomyces boulardii cultivated in liquid media at concentrations of $0.005,0.05,0.5,5,15$ and $25 \mathrm{mg} \mathrm{mL}^{-1}$.

The filtrates of the saprobes $C$. erogrostis, $C$. inaequalis and $P$. terrestris can induce resistance by activating the secondary defense mechanisms in bean hypocotyls, soybean cotyledons and sorghum mesocotyls, as shown in Figures 1, 2 and 3.

Phytoalexins occur naturally in many plant species. Phytoalexins are often found during phytopathogenic screening programs (GRAYER, KOKOBUN, 2001). Therefore, by analyzing phaseolin, glyceolin and deoxyanthocyanidins as indicators of resistance activation by the filtrates of $C$. eragrostidis, $C$. inaequalis, $P$. terrestris and $M$. echinata, it can be inferred that these saprobic fungi have the potential to elicit defense responses in plants such as beans, soybeans and sorghum. 


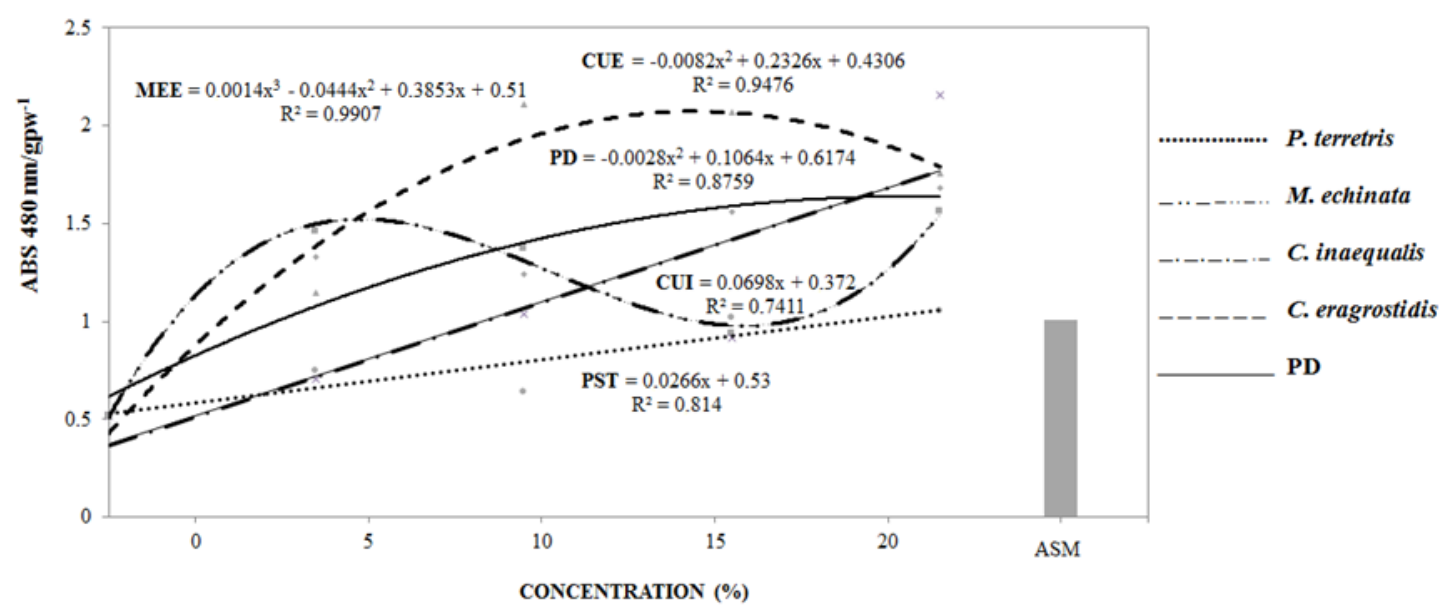

Figure 3. Accumulation of phytoalexins (deoxyanthocyanidins) in sorghum mesocotyls as a function of the application of the saprobric fungal filtrates of Memnoniella echinata, Curvularia eragrostidis, $C$. inaequalis and Pseudobotrytis terrestris at different concentrations. Potato dextrose (BD). Acibenzolar-S-methyl (ASM).

\section{CONCLUSIONS}

The filtrates of the saprobes $C$. erogrostis, $C$. inaequalis, $P$. terrestris and M. echinata promoted an increase in the accumulation of phaseolin.

The accumulation of deoxyanthocyanidins in sorghum mesocotyls increased with the application of the filtrates of $C$. eragrostidis, $C$. inaequalis, $P$. terrestris and M. echinata.

The filtrates of the saprobes $C$. erogrostis, $C$. inaequalis and $P$. terrestris promoted an increase in the accumulation of glyceolin.

\section{REFERENCES}

AHUJA, I. et al. Phytoalexins in defense against pathogens. Trends in Plant Science, Cambridge, v. 17, n. 2, p. 73-90, 2012.

ANDERSON, A. J. Isolation from three species of Colletotrichum of glucan-containing polysaccharides that elicit browning and phytoalexin production in bean. Phytopathology, Sant Paul, v. 68, n. 1, p. 189-194, 1977.

ARRUDA, R. S. et al. Efeito de extratos de cogumelos na indução de fitoalexinas e no controle de oídio da soja em casa de vegetação. Bioscience Journal, Uberlândia, v. 28, n. 2, p. 164-172, 2012.

AYERS, A. R. et al. Host-pathogen interactions. IX. Quantitative assays of elicitor activity and characterization of the elicitor present in the extracellular medium of cultures of Phytophthora megasperma var. sojae. Plant Physiology, Rockville, v. 57, n. 5, p. 751-759, 1976.

CHOUDHARY, D.; PRAKASH, A.; JOHRI, B. N. Induced systemic resistance (IRS) in plants: mechanism of action. Indian Journal Microbiology, Delhi, v. 47, n. 4, p. 289-297, 2007.

DIXON, R. A. et al. Phytoalexin induction in French bean: intercellular transmission of elicitation in cell suspension cultures and hypocotyl sections of Phaseolus vulgaris. Plant Physiology, Waterbury, v. 71, n. 2, p. 251-256, 1983.

DUBERY, I. A.; SANABRIA, N. M.; HUANG, J. C. Nonself perception in plant innate immunity. In: LOPES-LARREA, C. (Ed.). Self and nonself. Johannesbug: Landes Bioscience and Springer Science, 2012. v. 1, cap. 6, p. 79-107.

GRAYER, R.; KOKUBUN, T. Plant-fungal interactions: the search of phytoalexins and the other antifungal compounds from higher plants. Phytochemistry, Washington, v. 56, n. 3, p. 253-263, 2001.

IRITI, M.; FAORO, F. Chemical diversity and defense metabolism: how plants cope with pathogens and ozone pollution. International Journal of Molecular Sciences, Basel, v. 10, n. 8, p. 3371-3399, 2009.

MAZARO, S. M. et al. Indução de fitoalexinas em cotilédones de soja em resposta a derivados de folhas de pitangueira. Ciência Rural, Santa Maria, v. 38, n. 7, p. 1824-1829, 2008.

MAZARO, S. M. et al. Potencial de extratos à base de Calendula officinalis L. na indução da síntese de fitoalexinas e no efeito fungistático sobre Botrytis cinerea, in vitro. Revista Brasileira de Plantas Medicinais, Paulínia, v. 15, n. 2, p. 208-216, 2013.

NICHOLSON, R. L. et al. Phytoalexin synthesis by the sorghum mesocotyl in response to infection by pathogenic and nonpathogenic fungi. Proceedings of 
the National Academy of Sciences of the United States of America, Pasadena, v. 84, n. 16, p. $5520-5524,1987$.

NICHOLSON, R. L. et al. Phytoalexin synthesis in the juvenile sorghum leaf. Physiological and Molecular Plant Pathology, East Lansing, v. 33, n. 2, p. 271-278, 1988.

PEDRAS, M. S. C. et al. Phytoalexins and polar metabolites from the oilseeds canola and rapeseed: differential metabolic responses to the biotroph Albugo candida and to abiotic stress. Phytochemistry, Washington, v. 69, n. 4, p. 894-910, 2008.

PEDRAS, M. S. C. et al. The phytopathogenic fungus Alternaria brassicicola: phytotoxin production and phytoalexin elicitation. Phytochemistry, Washington, v. 70, n. 3, p. 394-402, 2009.

PEITER-BENINCA, C. et al. Indução de fitoalexinas e atividade de peroxidases em sorgo e soja tratados com extratos de basidiocarpos de Pycnoporus sanguineus. Arquivo do Instituto Biológico, São Paulo, v. 75, n. 3, p. 285-292, 2008.

SIMÕES, K. et al. Purification and characterization of a phytoalexin elicitor from spores of the saprobe Mucor ramosissimus. Revista Brasileira de Botânica, São Paulo, v. 28, n. 4, p. 735-744, 2005.

STANGARLIN, J. R. et al. Indução de fitoalexinas em soja e sorgo por preparações de Saccharomyces boulardii. Arquivos do Instituto Biológico, São Paulo, v. 77, n. 1, p. 91-98, 2010.

STANGARLIN, J. R. et al. A defesa vegetal contra fitopatógenos. Scientia Agrarias Paranaensis, Marechal Cândido Rondon, v. 10, n. 1, p. 18-46, 2011.

VIECELLI, C. A. et al. Indução de resistência em feijoeiro por filtrado de cultura de Pycnoporus sanguineus contra Pseudocercospora griseola. Tropical Plant Pathology, Brasília, v. 34, n. 2, p. 87-96, 2009.

WULFF, N. A.; PASCHOLATI, S. F. Preparação de Saccharomyces cerevisiae elicitoras de filtoalexinas em mesocótilos de sorgo. Scientia Agricola, Piracicaba, v. 55, n. 3, p. 138-143, 1998.

ZIEGLER, E.; PONTZEN, R. Specific inhibition of glucan-elicited glyceolin accumulation in soybeans by extracellular mannan-glycoprotein of Phytophthora megasperma f. sp. glycinea. Physiological Plant Pathology, Washington, v. 20, n. 3, p. 321-331, 1982. 